IIUC STUDIES

ISSN 1813-7733

Vol.- 7, December 2010

(Published in December 2011) (p 321-336)

\title{
The Objectives and Intents of Islamic Shari'ah As a Paradigm of Development Strategies and Policies
}

\author{
Dr. Mohammad Monzur-E-Elahi*
}

\begin{abstract}
The paper presents that the theory of objectives and intents of Islamic Shari'ah, which is termed as Maqasid alShari'ah al-Islamiyah, can provide a vision through which present and future changes and development of the Mankind can be proactively defined, negotiated, led and persuaded. It addresses the issue of the objectives of Islamic Shari'ah not only as a tool for the development within the traditional framework of our legal thought and practice, but within a more extended spectrum of thought that brings the concept of the objectives of Islamic Shari'ah to the overall development as well as the reconstruction of the Muslim thought, personality, culture and civilization. The theme showed in the paper is that the Knowledge of the Objectives of Islamic Shari'ah can play an important role as a universal paradigm in enhancing the abilities and qualities of the Ummah to reach a positive change and development from the present situation. But there is a need to review the Framework based on the Knowledge of the Objectives of Islamic Shari'ah in order to ensure its effectiveness in providing the necessary principles, methods and guidelines required in the processes of development strategy. Thus the paper suggests the ways of restoring back the sense of dynamism to the objective approach of Islamic Shari'ah in creating the methodological, social, educational, epistemological and cultural frameworks as a paradigm of development strategies, policies and processes for the betterment of the contemporary Muslim Ummah.
\end{abstract}

\section{Introduction}

Islam provides a complete code of life, encompassing all dimensions of human life. The Law of Islam as a complete way of life and a

*Assistant Professor, Dept of Islamic Studies, National University, Gazipur-1704 
universal call to all mankind has specific objectives and aims. These objectives revolve mainly around the interest and well-being of human beings in this world and in the hereafter. In fact, removing hardship and mischief from human life is the core interest of Islamic law which also attempts to bring ease and benefits to the life. ${ }^{i}$

The laws of Islam aspire towards establishing and preserving human interests and the entire teachings of Islamic law are meant to provide the necessary guidelines, principles, values and ways which are suitable and capable of achieving what is in the best interest and benefit of people. ${ }^{\text {ii }}$ As a practical manifestation and response to the appeals and aspirations of Islamic law a comprehensive and rich legal system had been introduced and developed by Muslim scholars and jurists, particularly in the days of glory and balanced civilizational development of the Muslim society. In later stages this guided legal system came to be known as al-Fiqh al-Islami or what we term today as Islamic jurisprudence. This legal system, as a human endeavor that had been guided by the principles and teachings of Islamic Shari'ah, has matured and enriched its legal legacy throughout the course of Islamic history. In its development and maturation process, Islamic law has consumed huge efforts and long stages of systematic and gradual accumulation of legal knowledge and wisdom. ${ }^{\text {iii }}$

In fact, the theory of the objectives of Islamic Shari'ah or the Maqasid paradigm was not only an approach for legal thinking and Ijtihad but also shown its ability to be a mature and well structured system for socio-cultural orientation and development of the Muslim community to achieve its goal as a Allah- fearing community, which we shall try to expose in the bellow.

\section{Definition of the objectives and intents of Islamic Shari'ah}

As we stated before that the theory of the objectives and intents of Islamic law is termed as Maqasid al-Shari'ah, we need to define these two Arabic words in brief. The singular form of maqasid is maqsad or maqsid whose literal meaning is 'destination'. Its trilateral root word is qasada with various meanings as to intend, to mean. Qasada ila means to go to, to head for (tawajjuh), to take to and to be bound for. Another derivative from qasada is qasd which means intention (niyyah), purpose, aim, end, intent, goal and objective (ghayah). 
Meanwhile, the term Shari'ah is also an Arabic word derived from its trilateral shara-'a. Shara'a $f i$ thus means to begin, to start, to commence, to go into, to enter upon.

But sharra' $a$ has an elementary meaning of 'creating' like to enact. Thus, the word Shari'ah is understood as law (qanun) or code. Hence, al-Shari'ah al-Islamiyyah is translated as Islamic law. Its literal meaning however is path or street.

At any rate, the use of Shari'ah in the context of Islam always refers to 'Islamic Shari'ah either in the sense of Islamic law or Islamic path which is in essence the same as the former i.e. Islam itself. In fact, even Islamic Shari'ah has its general and specific meanings. Its general sense refers to the entire system of life revealed by Allah to mankind. When the two words are combined, they form maqasid alShari'ah whose meanings can be discerned quite clearly. Thus, maqasid al-Shari'ah is variously translated as the objectives and intents of Islamic law, purposes and goals of Islam and so on. The phrase itself has been regarded variously as a subject, a theory, a set of principles etc. It is defined as the purpose and wisdom behind the enactment of all or most of the Shari'ah rulings. ${ }^{\text {iv }}$ Some scholars defined it as "The end sought behind the enactment of each of the rulings of Shari'ah and the secrets (wisdom) involved". "

These definitions explain that the objectives of the Islamic Shari'ah are the ultimate intention behind the enactment of each of the rulings of the Shari'ah and wisdom involved in these rulings. The end includes development of the world and the preservation of a system of coexistence and maintenance of the good on earth through the betterment of people who are obliged to lead their life justly and virtuously and to do and think for the good of the world and its occupants. The secrets in the above definition refer to the partial goals intended by the Lawgiver (Allah) in the enactment of the laws.

The purpose and wisdom of Islamic Shari'ah as well as the end includes various developments in life including the system of $m u$ 'amalah (civil transactions) etc. It also refers to partial goals intended by the Lawgiver in enacting the rulings of Islamic Shari'ah. Some of the wisdoms are defined by the Lawgiver in the Quran or in the Sunnah and some are left to be defined by the knowledgeable people. 
In essence, maqasid al-Shari'ah contains teachings about matters related to the translation of Islamic teachings into practice either at individual or societal level. As a broad framework, it mainly provides a set of general principles, maxims (qawa'id), methodologies and criteria needed for the construction of specific prescriptions for implementing Islam in changing and fluctuating circumstances and contexts. From another perspective, maqasid al-Shari'ah is regarded as a major component in usul al-fiqh subject. Depending on how one sees it, the position of maqasid al-Shari'ah in Usul al-Fiqh, although not always uniform, it is nonetheless very important.

\section{Examples of the objectives of Islamic Shari'ah}

The Qur'an is expressive, in numerous places and in a variety of contexts, of the purpose, rationale and benefit of its laws, to the extent that the texts stipulating these laws are characteristically goal-oriented. This feature of the Qur'an is common to its laws relating to both 'ibadah (ritual worship) and mu'amalah. Thus, when the text expounds on the ritual of wudu', or ablution for prayer, it adds:

"Allah does not wish to inflict hardship on you but to make you clean and to complete His favour upon you". [ Al-Quran, al-Maidah 5 : 7]

With regard to the prayer itself, it declares: "Truly, Salah restrains promiscuity and evil". [ Al-Quran, al-'Ankabut 29 : 45] With reference to Jihad the Qur'an similarly proclaims its rationale: "Permission is granted to those who fight because they have been wronged". [Al-Quran, al-Hajj 22 : 39] The purpose, in other words, of legalising Jihad is to fight zulm (injustice), and of Salah, to attain spiritual purity and excellence, which is accomplished together with physical cleanliness through ablution before the prayer. With reference to the law of Qisas (just retaliation), the text similarly adds: "And in the Law of Qisas there is life for you, O people of understanding”. [AlQuran, al-Baqarah 2 : 179] And finally, with regard to Zakah (wealth Tax), the rationale is also given: "In order that wealth may not circulate only amongst the rich". [Al-Quran, al-Hashr 59: 7]

One can add many more examples to demonstrate how the Qur'an and Sunnah are expressive of the goal, justification and benefit of their laws. In addition to the above, which require or sanction the undertaking of some positive actions, one may also refer to the ahkam of Islamic Shari'ah which prohibit or discourage certain actions that are or may be harmful and that may result in prejudice, corruption and 
injustice. In all cases, whatever the aim or justification of the individual laws, however, it is to be noted that the underlying objective is the realisation of some maslahah (benefit) for the community of the society.

\section{Introducing development}

Development is a major concern of the time. It has been one of the most popular and widely used terms in the different branches of Social Sciences in the post World War II period. ${ }^{\mathrm{vi}}$ Theorists both in the tradition of Western Liberalism and those who have opposed it have dwelt at length on the wide dimensions of the concept as well as the nature and scope of the term. According to Joseph E. Stiglitz " Development represents a transformation of society, a movement from traditional relations, traditional ways of thinking, traditional ways of dealing with health and education, traditional methods of production, to more "modern" ways."vii Change in his opinion is not an end in itself, but a mean to other objectives. The changes that are associated with development provide individuals and societies more control over their own destiny. Development enriches the lives of individuals by widening their horizons and reducing their sense of isolation. It reduces the afflictions brought on by disease and poverty, not only increasing life spans, but improving the vitality of life. Given this definition of development, it is clear that a development strategy must be aimed at facilitating the transformation of society, in identifying the barriers to, as well as potential catalysts for, change. ${ }^{\text {viii }}$

\section{Islamic Concept of Development}

In Islam development means all kinds of positive changes. The Islamic conception of human development can easily be understood from the following verse of the Qur'an :

"Verily, God does not change men's condition unless they change their inner selves. "[ Al-Qur'an, ar-Ra'ad $13: 11]$

"And among them he who says, 'our Lord, give us in this world (that which is) good and in the hereafter (that which is) good and protect us from the punishment of the fire.' Those will have a share of what they have earned."

[ Al-Qur'an, al-Baqarah 2 : 201] 
The paradox is that the Islam and Islamic values stand for development, both morally and materially, so much so that one is commanded to disperse in the world after prayers to seek the bounty of Allah, ${ }^{\text {ix }}$ and ordained to explore, develop and make use of all the resources fully and optimally.

Islam guides human development on correct lines and deals with all dimensions of economic development in the framework of total human development. Dr Abul Hasan M Sadeq defines economic development in Islam as balanced and sustained improvement in material and nonmaterial well-being of man that is not complete without a high moral standard resulting from Islamic values and it is a factor in the welfare of human beings in the life hereafter as in this worldly life. ${ }^{\mathrm{x}}$ Thus the development in Islam is featured by : (1) a comprehensive character, including moral, spiritual and material aspects of human life; (2) the development of man and his physical and socio-cultural environment; (3) a balance between factors and forces; (4) a number of changes, quantitative as well as qualitative, with due emphasis to qualitative changes; and (5) the optimal utilisation of resources and their equitable utilisation and distribution on the basis of right and justice. ${ }^{\mathrm{xi}}$

The objectives and priorities of development in Islam include growth, fulfillment of the basic human needs -material and spiritual, educational and civilisational - human resource development, distributive justice and preservation of religion, life, intellect, honour, rights and environment etc.

In Islam Development needs to be understood as a multidimensional approach that satisfies the socio-economic and politico-security indicators. Because only the economic success cannot be considered in Islam as a phenomenon of development, rather we should understand the dynamics of development by concentrating on a holistic approach of development, which is showed in the following diagram. 


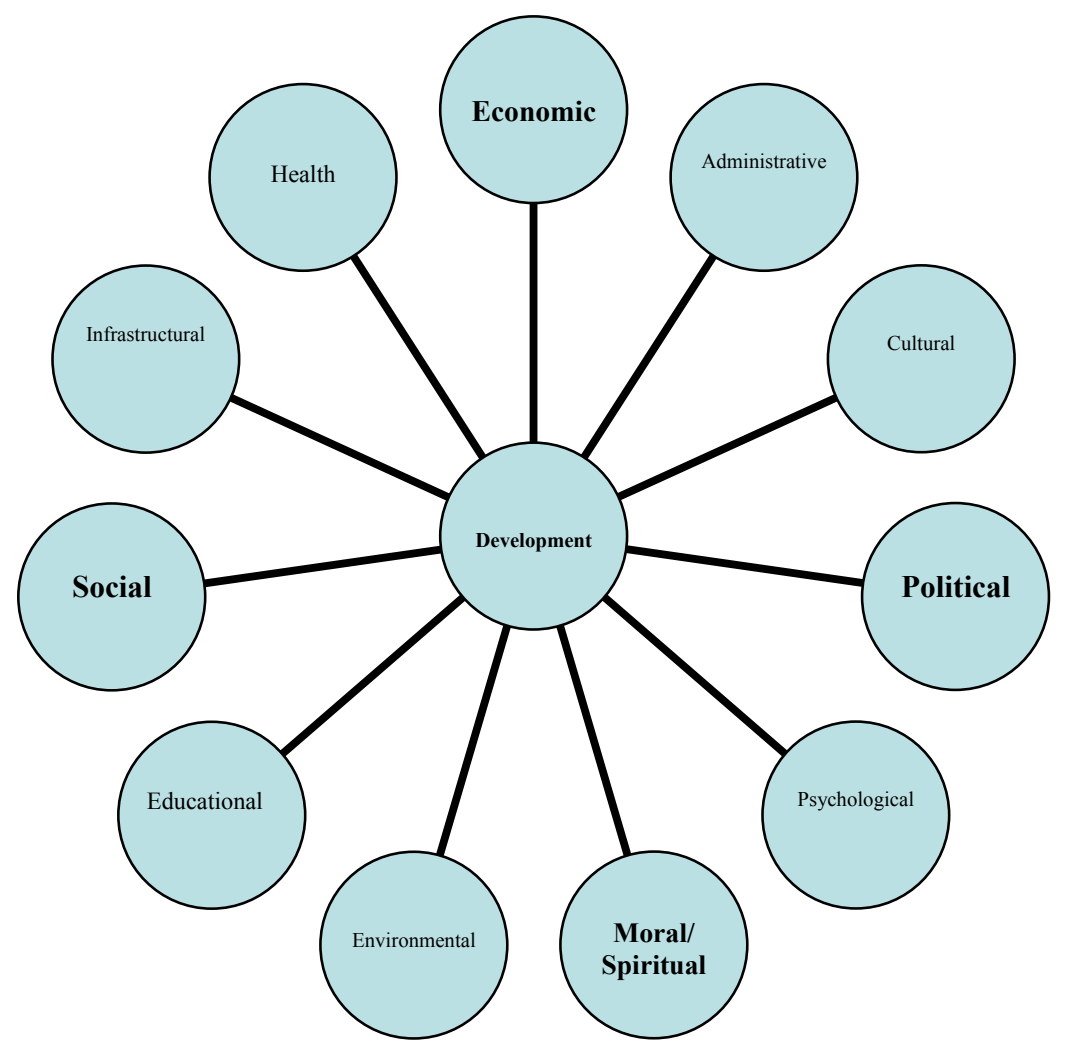

\section{Development Issues in the objectives of Islamic Shari'ah}

Islamic discourses and practices have advanced with non-uniform realisation in recent years in the fields of Economics, Education, Environment and Science. This shows that Muslim thinkers and actors are indeed consciously seeking intellectual insight, meaning and practical advancement through studying Islamic concepts, and the Muslim worldview in the present social context. Given that Maqasid al- Shari'ah are attracting increased attention in the epistemic community of fiqh, is it appropriate to envision a Maqasid based Development as a framework for the ennoblement of Muslim societies that is driven, inspired by discerning understandings of the objectives of Islam?

Islamic Shari'ah started with the advent of Islam. The overall goal of the Islamic Shari'ah is to promote welfare (masalih) of mankind. This 
goal in broad general terms implies, among others, to ensure development and justice and in specific terms relates to the objectives of Islamic Shari'ah (Maqasid al-Shari'ah) implying the protection of religion, life, intellect, progeny and property. ${ }^{\mathrm{x}}$

Undoubtedly, all objectives of Islamic Shari'ah revolve around man's interest in this world and in the hereafter. In this respect, the most important thing that needs to be clarified is the role of objectives (Maqasid) in any new legal, intellectual and civilisational renewal of the Ummah. Surveying the legal texts in the context of the objectives of Islamic law it is known that one of the main goals of Shari'ah is to serve and protect the interests of entire people. Indeed, in the framework and spirit of the divine law of Islam, public interest and the well being of humanity, be it in this world or in the hereafter, becomes one of the most vital issues of more merit and value. No doubt that the entire law of Islam runs through the vein of 'human interest' which can be expressed in another word human development. In fact, whatever thing that is for the benefit and success of humanity in this world and in the hereafter the law of Islam always supports it and provides the necessary means, principles and values to establish and preserve it. For instance, if man in this world strives to achieve justice, equality, dignity, honor, freedom, tolerance, mercy, peace, security, stability, moderation, co-existence and balance in human life, the law of Islam does not only speaks of these values but also sets the necessary guidelines, principles and ways that can ensure their realization in human context and reality. To support this claim, we mentioned in the bellow few selected verses from the Qur'an which will serve the purpose. Allah SWT says:

"Indeed, Allah commands you to render back the trusts to whom they are due; and when you judge among people, to judge with justice". [ Al-Quran, an-Nisa 4 : 58]

"And we have not sent you, except as a mercy to the worlds". [ AlQuran, al-Anbiya 21:107]

"If any one slew a person-unless it be for murder or for spreading corruption in the land-it would be as if he slew the whole mankind and if anyone saved a life, it would be as if he saved the life of the whole mankind"'.[ Al-Quran, al-Maidah 5 : 32] 
"O ye who believe' Enter into peace wholeheartedly; and follow not the footsteps of the Evil one". [ Al-Quran, al-Baqarah 2 : 208]

"And We have certainly honored the children of Adam; provided them with transport on land and sea; Given them for sustenance things good and pure; and conferred on the special favors, above a great part of our creation".'[ Al-Quran, al-Isra 17 : 70]

"Allah forbids you not, with regard to those who fight you not for (your) fight nor drive you out of your homes, from dealing kindly and justly with them: for Allah loves those who are just". [ Al-Quran, alMumtahina $60: 8]$

"Yet there be no compulsion in religion: Truth stands out clear from error". [ Al-Quran, al-Baqarah 2 : 256]

"O mankind' Indeed We created you from a male and a female, and made you into nations and tribes, that you may know one another. Indeed, the most honored of you in the sight of Allah is (he who is) the most righteous of you".'[ Al-Quran, al-Hujrat 49: 13]

"But seek, through that which Allah has given you, the Home of the hereafter; and do not forget your portion in this world. And do good as Allah has done good to you. And desire no corruption in the land. Indeed, Allah does not like corrupters". [ Al-Quran, al-Qasas 28:77]

These verses of the Noble Qur'an showed that the Islamic Shari'ah aims at the development of the whole world in a just, proper and righteous way. On the other hand, it should be clear that the Islamic Shari'ah hasn't only made man's interest as its main objectives, but also it provided us with the core characteristics of its vision and way and procedure of establishing the development and applying it to the human context.

To go one step further in our discussion about human interest and development as the main purpose of the law of Islam it is important to refer to the views of some classical Muslim scholars. Indeed, anything that falls within the framework of protecting human public interest and 
development constitutes the core of the Shari'ah objectives (Maqasid al-Shari'ah). .iii $^{\text {xii }}$

Imam al-Ghazali splendidly argues that:

"Maslahah (public interest) is the protection of the objectives of the Shari'ah which consists of five values: preservation of religion, of life, of intellect, of progeny and of wealth. What assures the protection of these five values is maslahah (public interest), and whatever leads to its lost is considered mafsadah (mischief) and its prevention and removal is maslahah". xiv

In line with this, another author has argued that:

"The purpose of Shari'ah as determined by al-Ghazali, and agreed to by most jurists including al-Shatibi, are first of two types: 'dini' or purposes of the hereafter and dunyawi or purposes pertaining to this world. The worldly purposes are further divided into four types: the preservation of life, the preservation of progeny, the preservation of intellect and the preservation of wealth. These different types taken together yield five ultimate purposes of the law: the religion, life, progeny, intellect, and wealth. All five purposes are called al-Daruriyyat (necessities) and are the primary purposes of the law. The Daruriyyat are followed by the Hajiyyat (needs), which are additional purposes needed by the primary purposes. The third category is that of purposes that seek to establish ease and facility. These are referred to as Tahsiniyyat or complementary purposes". ${ }^{\mathrm{xv}}$

\section{The Objectives of Islamic Shari'ah (Maqasid) as a paradigm of development}

With unsuccessfulness of the existing development paradigms according to the opinion of Dr Joseph E Stiglitz and in quest for a new paradigm of development, we can propose a more holistic paradigm of development based on the objectives and intents of Islamic law, as they are potent Islamic values that provide a vision broadening and common conceptual language through which present and future 
development can be proactively defined, negotiated, led and persuaded. At the same time, the whole humanity is in a period of nonuniform dysfunction, restlessness and hardship. Conventional development paradigms and the interests and values that they carry and impose have been practically and theoretically discredited and there is a global search for superior alternatives. ${ }^{\text {xvi }}$ In the quest for advancement, the objectives of Shari'ah (Maqasid al-Shari'ah) are important values that individuals and institutions can interpret and act upon. The translation of such theory into reality could be termed 'Maqasid based development'.

\section{Maqasid and the overall development of the contemporary Muslim Society}

Maqasid based development discourse could be beneficially transfused into three distinct. These are the political-administrative structure, the Muslim knowledge culture and the general Muslims. ${ }^{\text {xvii }}$

The values conveyed in the Maqasid of the law of Islam provide a great starting point for Muslims today to launch into study and action for the benefit of all, and particularly the upliftment of the Muslim society. It provides a common objective appeal constructed upon directions that we have been given in our primary textual sources. It will not be a panacea, but may act as a stimulant, a catalyst, or a detonation wave, for a genuinely participatory and qualitative advancement. The classification of Maqasid into al-Daruriyyat (Necessities), al-Hajiyyat (Needs) and al-Tahsiniyyat (Luxuries) can play a good role to fix theories and strategies of developments. According to Jasser Auda 'human development' is a prime expression of maslahah (public interest) in our time, which Maqasid al-Shari'ah should aim to realise through the Islamic Shari'ah. ${ }^{\text {xiii }}$ Thus realisation of this maqasid could be empirically measured via the UN 'human development targets', according to current scientific standards. The evolution of 'human development' into objectives and intents of Islamic law gives human development targets a firm base in the Islamic world. ${ }^{\text {xix }}$

\section{Maqasid and social Development}

Maqasid of Islamic Shari'ah allows flexibility, dynamism and creativity in social policy. According to Imam Al-Ghazali (d. 505H):

"The objective of the Islamic Shari'ah is to promote the well-being of all mankind, which lies in 
safeguarding their faith (din), their human self (nafs), their intellect ('aql), their posterity (nasl) and their wealth ( $\mathrm{mal}$ ). Whatever ensures the safeguard of these five serves public interest and is desirable." $\mathrm{xx}$

Al-Shatibi (d.1388) approves al-Ghazali's list and sequence, thereby indicating that they are the most preferable in terms of their harmony with the essence of the law of Islam. ${ }^{\text {xxi }}$

Generally, Islamic Shari'ah is predicated on benefits of the individual and that of the community, and its laws are designed so as to protect these benefits, and facilitate improvement and perfection of human lives' conditions on earth. This perfection corresponds to the purposes of the Hereafter. In other words, each of the worldly purposes (preservation of faith, life, posterity, intellect and wealth) is meant to serve the single religious purpose of the Hereafter.

The uppermost objectives of Shari'ah rest within the concept of compassion and guidance, that seeks to establish justice, eliminate prejudice and alleviate hardship. It promotes cooperation and mutual supports within the family and society at large. This is manifested in the realisation of maslahah (public interest) which the Islamic scholars have generally considered to be the all-pervasive value and objective of the Islamic Shari'ah and is to all intents and purposes synonymous with compassion.

In the light of the preceding discussion of the objectives of Islamic Shari'ah, social responsibility assumes a broader and more holistic significance to the Muslim workers, managers, corporations, customers and society as a whole. Obviously, the concept of social responsibility in Islam encompasses a broader meaning embracing the Taqwa dimension (Allah-consciousness) by which corporations as groups of individuals, assume the roles and responsibilities as servants of Allah in all situations. By assuming such roles, they are ultimately responsible to Allah, the Owner of their very selves and the resources they are utilising and managing. This responsibility to Allah is, in fact, a function of the intrinsic quality of the Muslims' lives as a trust from Allah. ${ }^{\text {xxii }}$

A Muslim is, in fact, considered as a social being who cannot isolate or ignore his role and responsibility to the society or any of his fellow human being such that he is discouraged to isolate himself even for the 
purpose of worshipping Allah. The invocation of Islamic Shari'ah and the reflection of Taqwa-paradigm in all spheres of life imply that the people are no longer driven by the principle of self interest alone, but by the pursuit of the ultimate happiness in this life and the Hereafter, whereby he acknowledged his social and moral responsibility for the well-being of his fellowmen.

\section{Maqasid and Muslim intellectual reform and civilizational renewal The Maqasid Framework can play an important role in enhancing the Ummah's abilities and qualities of intellectual reform and civilisational renewal. It could become an approach for the orientation of the different activities pertaining to the civilisational reawakening of the Ummah. It could form the epistemological and philosophical scaffold for directing the theories, sources and objectives of civilisational renewal. It could also constitute the ethical and educational reference for guiding the activities of social and civilisational transformation of the Ummah. Moreover, it could assist in discovering the laws and pattern of civilisational transformation. In all these activities the Maqasidi framework can provide principles, guidelines and methods of discovering and implementation of the objectives of Islam in a real practical context.}

\section{Maqasid and Islamic finance and Banking}

Islamic finance was revived at institutional level with the establishment of Islamic banks during the last quarter of the 20th century. Along with the new institutions of Islamic banks, Islamic insurance companies and other Islamic finance companies came out on new "financing" practices of a few classical contracts like Mudaraba, Musharaka, Istisna etc.

The objectives of the Shari'ah in financial transactions refer to the overall goals and meaning that the Shari'ah aims at achieving from its rulings. These objectives are not confined to one type of financial transaction, but include all aspects of financial activities and human life in general.

Though these objectives seem specific as they deal with finance, they can be considered as integral objectives when their universal goals are considered. This is because such objectives do not deal with specific types of rulings, but they are related to almost all types of financial transactions and involve all activities of trading, profit making, spending and consumption. Allah says: 
"There is not a moving (living) creature on earth, nor a bird that flies with its two wings, but are communities like you. We have neglected nothing in the Book, then to their Lord they (all) shall be gathered".[ Al-Quran, al-An'am $6: 38]$

Looking deeply and constantly into several texts or verses of the Qur'an and the Sunnah of the Prophet (PBUH) on financial activities, it can be stated that the Shari'ah has observed specific objectives in the enactment of financial laws and principles.

These objectives include the circulation of wealth in the society, the continuity of the investment of the wealth, achieving the economic prosperity for the whole society by satisfying the basic needs of the people, transparency in financial activities to eliminate disputes and permissibility of private and public ownership of the wealth. These are the main objectives of Shari'ah in financial transactions and contracts. All the above objectives falls under the general meaning of the following verses of al-Qur'an :

"Allah does not want to place you in difficulty, but He wants to purify you, and to complete His Favour to you that you may be thankful". [ Al-Quran, al-Maidah $5: 6]$

Allah also says in another ayah :

“...Allah intends for you ease, and He does not want to make things difficult for you....". [ Al-Quran, al-Baqarah 2 : 185]

It is observed that, unfortunately, no serious effort has been made to fix the clear objectives of Islamic banking. What can be seen in many literatures are scanty and disjointed discussions about the objectives of Islamic Banks. It has been taken for granted that Islamic Banks are only about avoiding riba (interest). Rather there must be many basic important objectives of Islamic Banking which should be identified and from the theory of Maqasid al-Shari'ah, the ideal objectives of Islamic Banking can be identified. And based on those objectives a model of Islamic Banking performance can be developed.

\section{Conclusion}

The objectives of Islamic law (maqasid) have become the focus of attention as it tends to provide ready and convenient access to the 
development of not only the Muslim Ummah but also the whole mankind. An adequate knowledge of the objectives of Islamic Shari'ah can easily equip the Muslims with insight and provide them with a theoretical framework in which the practical attempt to pursue the development work for the welfare of the contemporary society can be more meaningful and interesting. Thus the knowledge of the Objectives of Islamic Shari'ah (Maqasid) can be an effective paradigm for the development, although it is still a necessity to transfuse the concept of Maqasid into contemporary fields of action as development strategies, policies and process.

\section{References:}

i Abdelaziz Berghout, Maqasid Shariah as an approach for intellectual reform and civilizational renewal, article submitted to the nternational Conference on Islamic Jurisprudence and the Challenges of the $21^{\text {st }}$ Century, IIUM, Malaysia, 2006 p.44

ii Abu Ishaq al-Shatibi, al-Muafaqat Fi usul al-Shariah, Ed., Sheikh Abdullah Darraz, (Cairo, al-Maktabah al-Tijariyah al-Kubra, N.D.) Vol.2 Pp. 168 and 6.

iii Abdelaziz Berghout, Maqasid Shari'ah as an approach for intellectual reform and civilizational renewal, p.45

iv Muhammad al-Taher Ibn 'Ashur, Maqasid al- Shari'ah al-Islamiyah, Dar al-Nafais Publications, Amman, Jordan, 2001, p. 188

v 'Allal al-Fasi, Maqasid al-Shari'ah al-Islamiyah wa Makarimuha,Dar al-Gharb al-Islami, Morocco, 1991, p.7

vi Muhammad Ruhul Amin, Development Issues and Strategies of Bangladesh : Lessons From Malaysia, Center for International Development and Security, Dhaka, 2006 p.36

vii Stiglitz, J. E. , Towards a New Paradigm for Development: Strategies, Policies, and Processes, Given as the 1998 Prebisch Lecture at UNCTAD, Geneva, p.3

viii Ibid.

ix Al-Qur'an, al-Jumu'ah $62: 10$

x Abul Hasan M Sadeq, Development Isuues in Islam, Reseach Centre, International Islamic university, Malaysia, 2006 p.3

xi Ibid. 
xii See Siddiqi (2004a and 2004b) for a discussion on the objectives of Shari'ah.

xiii Al-Juwayni 'Abd Al-Mali Imam Al-Haramayn, Al-Burhan Fi 'Usul AlFigh (Doha: Jami' Qatar, 1399) Allal Fasi, Maqasid Al-Shari 'ah AlIslamiyyah Wa Makarimuha (Casablanca: Al- Najah,1956).

xiv Abu Hammd Al-Ghazzli, Al-Mustasfa min 'Ilm al-'Usul, Vol. 1 (Baghdad: Matba'at Muthanna, 1870), Pp. 286-287. 16

xv Abu Ishaq al-Shatibi, Al-Muwafaqat fi Usul al-Shariah, Ed., Shaykh 'Abd Allah Darraz, (Cairo: al-Maktabah al-Tijjriyyah al-Kubra, N.D.), Vol. 2, P. 8-13.

xvi Joseph E Stiglitz criticized the existing conventional development paradigms, because they are not successful in their development goals and that's why was looking for a new paradigm of development. He says, " I want to go beyond these by now well-documented failures of the Washington consensus to begin providing the foundations of an alternative paradigm, especially one relevant to the least developing country. It is based on a broad conception of development, with a concomitantly broader vision of development strategies and a quite different perspective on the role of international assistance and the ways in which it should be delivered." Towards a New Paradigm for Development: Strategies, Policies, and Processes, P.2, He suggested a framework for his new paradigm of development strategies that focuses on five levels : (a) Private sector development, (b) Public Sector Development, (c) Community development,(d) Family development, (e) Individual development, p.24-27

xvii Fuad Mukarram Munawwar Ali, Towards an Easily Accessible Framework for the Ummah's Advancement : Maqsid based Development, IIUM, 2006 p.158-164

xviii Jasser Auda, Maqasid al-shariah As Philosophy of Islamic Law, IIIT, USA, 2008 p. 25

xix Ibid, Mohammad Shakir alsharif, Haqiqah al-Dimuqratiyah, Dar alWatan, Riyadh 1992 p.3

xx Abu Hamed al-Gazali, al-Mustasfa, United Publications Co, Egypt, p. 251

xxi Abu Ishaq al-Shatibi, al-Muafaqat Fi Usulis Shari'ah, vol. 3 p. 46-47

xxii Al-Attas, S. M. N., Islam and the challenge of Modernity, Kuala Lumpur, International Institute of Islamic Thought and Civilization, Malaysia, 1996, p. 284 